\title{
Katarzyna Cymbranowicz
}

Cracow University of Economics

Faculty of Economics and International Relations

Department of European Economic Integration

e-mail: cymbrank@uek.krakow.pl

\section{The phenomenon of the precariat in the Polish labour market during Poland's membership in the European Union*}

\begin{abstract}
Studies of the scale of unemployment in Poland and in Europe conducted in recent years lead to the conclusion that one of the largest and growing problems of the modern labour market is the unemployment rate among young people. An unfavourable phenomenon related to this issue, which is increasingly often appearing in public debate, is the rising unemployment of graduates. Therefore, it is important to attempt to identify related phenomena in today's job market, and one of such phenomena is the emergence of a new type of employee in the labour market, a member of the precarious class.

The analysis aims to present the origins, nature and scale of the precariat phenomenon in Poland. The issue is described from the perspective of the labour market position of a selected social group, i.e. young people entering the labour market after finishing their education. The study attempted to identify factors that affect this phenomenon and the characteristics confirming the sense of its separateness in the labour market.
\end{abstract}

Keywords: precariat, labour market, non-standard forms of employment

JEL Classification: E24, J31

\footnotetext{
* The article is a revised and updated version of the paper published in Polish in the Annales. Ethics in Economic Life, 19(2), 17-30.
} 


\section{Introduction}

Studies of the scale and structure of the phenomenon of unemployment conducted in recent years have often led to the conclusion that unemployment among young people, including university graduates, is one of the largest and fastest growing problems. An important reason for undertaking the analysis of this issue is the increasing scope of this phenomenon, both in Poland and abroad, and the formation of a new class of employees, especially among people just entering the labour market, which can significantly affect the social and economic development of the country.

In the first part of the article discusses the terminology issues related to the precariat, precarious work and members of the precariat. The second part presents the scale of the precariat phenomenon in Poland and possible changes in the Polish labour market in the context of this phenomenon. The research hypothesis is that there is a problem of precarious employment in Poland. In view of the above, the aim of the article is to present the origins, nature and scale of this phenomenon in the Polish labour market. The implementation of this aim will be possible based on studies of domestic and foreign literature as well as statistical analysis of selected labour market indicators obtained from the European Statistical Office database (Eurostat).

\section{The precariat and precarious work-terminology issues}

The concept of precariat appeared for the first time in social sciences in the 1980s in order to describe the situation of temporary and seasonal workers, ${ }^{1}$ although it became more popular in the first decade of the $21^{\text {st }}$ century. It was formed by combining two words, i.e. precarious (uncertain) and proletariat (poor working class), and in this foreign form it has permanently entered the Polish language dictionary.

One of the proponents of this concept, which is increasingly often appearing in the public discourse, is Guy Standing. The precariat is a population that is difficult to define, as Standing emphasises in the book entitled The Precariat: The New Dangerous Class (2011a), where he puts forward the hypothesis about the emergence of a new, separate, highly internally diverse socio-economic group with a global reach called the precariat. ${ }^{2}$ The precariat is defined as a social class $^{3}$

\footnotetext{
${ }^{1}$ The term has been used, among others, by: Paul Michel Foucault-a French philosopher, historian and sociologist, Antonio Negri-an Italian ethicist, philosopher and writer, Pierre-Félix Bourdieua French sociologist, anthropologist and philosopher, as well as Jürgen Habermas - a German philosopher and sociologist.

${ }^{2}$ In the Polish magazine "Polityka", in his article entitled Prekariusze wszystkich krajów [The Precariat of the World] of September 2011, Smoczyński wrote: "A new social class is growing in Europe, without prospects for prosperity and advancement. It also exists in Poland and has its name: the precariat."

${ }^{3}$ However, this is not a social class in the Marxist or Weberian sense.
} 
whose characteristic feature is uncertainty (English: precarious, French: précarité). Filip Vostal, who associates the concept of precariat with a state that is uncertain, insecure or unstable, supports this position (2014, p. 39). It should be emphasised, however, that Standing does not reduce the state of uncertainty only to "poor occupational content, insecure and low-paid work" (Kozek, 2013, p. 145), but he draws attention to other, equally important issues distinguishing the precariat from other social classes. Additionally, stability and security of employment or minimum work protection (which concerns the people temporarily unemployed, supporting themselves from temporary jobs, employed on the basis of short-term contracts, or migrating in search of income), there is a more important issue regarding the lack of career opportunities as members of the precariat are deprived of a sense of professional identity. In his opinion, the so-called precarious work ${ }^{4}$ does not provide development opportunities because people

[...] are in career-less jobs, without traditions of social memory, a feeling they belong to an occupational community steeped in stable practices, codes of ethics and norms of behaviour, reciprocity and fraternity. The precariat does not feel part of a solidaristic labour community. This intensifies a sense of alienation and instrumentality in what they have to do. (Standing, 2011a, p. 12)

In contrast to Standing, many disagree with the idea that the precariat is to be a new social class that because of its growing numbers is becoming increasingly dangerous (Jourdan, 2012). Ryszard Szarfenberg argues that creating an analogy between the precariat and the proletariat is not entirely justified. His position is because today we are not dealing with a situation that "would contribute to the creation of a class or a cohesive group around which one builds one's identity, as was the case with the proletariat" (Hanyga, 2012).

Thus, it seems reasonable to ask the question of what is actually the relationship between the precariat and the proletariat, between the representative of the first and the latter group. Standing (2011a, p. 137), claiming that anyone, regardless of age, job seniority or education, can become a member of the precariat. In other words, all social groups - feed the precariat by those who are precarised, ${ }^{5}$ i.e. "subject to pressures and experiences that lead to a precariat existence, of living in the present, without a secure identity or sense of development achieved through work and lifestyle" (p. 60). To sum up, according to Standing, a member

\footnotetext{
4 “[...] Precarious forms of employment are defined (Rodgers, 1989) with regard to the certainty with which employment may be maintained in the long-term perspective, the degree of control over working conditions, the degree of protection of the workplace and working conditions by the applicable provisions, and the possibility of claiming one's rights and determining one's earnings. Various additional features, such as non-pay employee benefits, autonomy in performing tasks at work, compliance of employment with qualifications, physical security and health conditions, or the possibility of reconciling work and family life are part of various characteristics and ways of measuring precarity [...]. In a slightly different convention (referring to the work of U. Beck), the risk of re-qualification, deterioration of working conditions, loss or reduction of income and dismissal as well as chances of representation, etc. are characteristic of precarious employment" (Poławski, 2012, p. 16).

5 This awkward word is analogous to "proletarised", describing the forces leading to the proletarianisation of workers in the $19^{\text {th }}$ century (Standing, 2011a, p. 60).
} 
of the precariat is a member of the proletariat of the $21^{\text {st }}$ century, i.e. a person who operates under conditions of constant uncertainty. The uncertainty he writes about is not one-dimensional. On the contrary, it is expressed in attitudes characteristic of the precariat, the so-called " $4 \mathrm{a}$ ", including (Standing, 2011b):

(1) Anxiety: "Uncertainty creates uninsurable risks for them. The satisfaction and fulfilment known to others, through vocation, is unknown to the precariat. The idea that a job gives an identity to be proud of is hollow and false to the precariat. The idea of a job as a key route to fulfilment, meaning identity, wellbeing and happiness is a mirage for the precariat. Their experience of employment is just the opposite."

(2) Anomie: "There is despair, in the lower reaches of the group, that escape to a better life is not possible. Prospects are low in the precariat, social mobility rare, and the possibility of improved and secure material living standards seems remote. Thus the group is increasingly excluded from the mainstream of society. This process of exclusion is giving rise to a particular mindset among the precariat. The combination of exclusion and uncertainty cause the precariat to flit around activities to keep options open by multiplying networks and activities, a process which is known to be stressful and associated with a number of social illnesses."

(3) Alienation: "Members of the precariat are forced to do too many things which they do not want to do in the sphere of employment. These combine to present an image of self which is contrary to a more desirable idea of self as an autonomous entity with some say over the major dimensions of how to live one's life. Such aspirations are dashed in the everyday lived experience of low pay and economic insecurity. Simultaneously, members of the precariat are not able to undertake roles and activities which do help to produce the possibility of a coherent and autonomous self. This also means that the precariat are at the same time overemployed, working long hours in low paid insecure jobs in the struggle to make ends meet and underemployed, and such jobs not requiring many of the skills, aptitudes or enthusiasms which characterise a flourishing human being. Thus the precariat are alienated from themselves, from each other and from others outside the precariat."

(4) Anger: "Unsurprisingly, the combination of the above factors is causing increasing anger among the precariat, turning to seething anger."

These attitudes lead to negative effects felt in the social and economic dimension.

Quoted earlier Standing (2011b, pp. 102-116) distinguished seven separate classes in the contemporary social structure: global citizens, salariat, proficians, working class/manual employees, the precariat, the unemployed, and a group of socially ill misfits. The division is based on studies carried out recently in the UK, which were based on the traditional occupational classification and scales of professions (Savage, 2013). Similarly, to Standing, seven social classes were distinguished, including the precariat as a separate class. These analyses, contrary to the ones conducted by Standing, do not include issues related to the concept of precariat and do not deal with the aspects of job uncertainty and security as key issues. 
It can be said that the precariat is classified as the secondary, and not primary, segment of the labour market:

The precarious segment of the labour market is a segment of excluded people operating on its periphery and not rooted in the corporate or industrial order of collective labour relations [...]. Precarious employment is - consistently-present in various segments of the social structure and occurs in various occupational groups, although to a different degree. Precarity in this sense is also a feature of the creative class and relatively well-educated and qualified workers, specialists or independent experts employed on the basis of contracts who share not so much the small amount of earnings with employees of the secondary labour market but rather, related to the temporary nature of employment, instability of income and relaxation of social protection guaranteed by appropriate regulations for full-time employees. In the corporate realities, also those categories that are classified in the Polish statistics as non-manual workers and in English-language literature as white-collars are subject to precarity. (Poławski, 2012, pp. 16-17)

Prof. Jolanta Szaban from Leon Kozminski Academy in Warsaw described the "white-collars" in Poland:

[...] officeariat - i.e. people doing simple office work for a low salary. Such work can be performed by anyone without special preparation. It is even said that it is usually done by the so-called "duci" (from the words "do it"), people desperate to take up any work and struggling to support themselves with this type of activity. In a number of other European countries, this category is less frequent due to the specificity of the situation of officials whose status is sometimes very high compared to Polish ones (e.g.: in Germany, France, Portugal, Greece). (2013, p. 23)

In Poland, the discussion on the precariat phenomenon began at the time of publishing of the report entitled Młodzi 2011 [Youth 2011] by Prof. Krystyna Szafraniec from Nicolaus Copernicus University in Torun. ${ }^{6}$ This multidimensional diagnosis was created because of the work of the interdisciplinary team that in 2010-2011 met in the Chancellery of the Prime Minister under the direction of Minister Michał Boni. One of the main problems discussed in the report is the situation of young people in the Polish labour market. The document shows that there is an increase in the number of temporary employment contracts in Poland.

\footnotetext{
${ }^{6}$ The publication is a detailed study of the results of research and analysis of many areas of life and functioning of young people in Poland: "The report shows the needs, problems and internal potential of the young generation. The basis of Młodzi 2011 [Youth 2011] report was the assumption that youth is one of the main resources on which the strategy of building modern society and state can be based as well as the thesis about a great innovative potential inherent in youth, especially when [...] society faces challenges to carry out deep, thorough reforms. The above-presented words refer to a new, strategic view on the socio-economic development of Poland which was initiated by another report prepared also under the direction of Minister Michał Boni, i.e. 'Polska 2030 - wyzwania rozwojowe' [Poland 2030 - Development Challenges].” Cf. Kancelaria Prezesa Rady Ministrów, 2011.
} 
According to statistical data, the percentage of such contracts in Poland is twice as high as in the European Union, which slowly leads to the creation of the dual labour market in our country:

\begin{abstract}
One market (internal) is taken by full-time employees focused on permanent employment and career providing an opportunity for advancement and growing income (the so-called insiders). The other market comprises temporary employees who live in an uncertain situation, are at risk of unemployment and have poor career prospects (the so-called outsiders). The dual labour market is becoming a particularly serious problem for young people as it may mean to them a permanent balancing act as an employee who is a perpetual apprentice. (Kancelaria Prezesa Rady Ministrów, 2011, p. 169)
\end{abstract}

The authors of "Młodzi 2011" (Youth 2011) report emphasise that temporary forms of employment have advantages and disadvantages: "they provide a chance to start in a profession [...] but at the same time they do not bring satisfaction in the form of a consistent, balanced career path, training participation, adequate insurance or guarantee of adequate income, or - which is even more importantlong-term income certainty, which would be a sign of creditworthiness for banks" (Kancelaria Prezesa Rady Ministrów, 2011, p. 394), especially important are the mortgage loans. The authors of the report, comparing the status of the young people in the $20^{\text {th }}$ and $21^{\text {st }}$ century, conclude that contemporary youth entering the labour market is, on average, older, definitely better educated, has richer social and cultural experience and a different attitude to life and work.

In summary, the precariat combines several features. These include the young age, temporary employment or unemployment, low income, a lack of housing, and often a lack of family or reluctance to start one due to financial instability. These add up to a lack of life prospects and formulation of financial plans for the future.

\title{
3. The scale of the precariat phenomenon in the labour market in Poland compared to the European Union
}

This part of the article will provide an overview of the socio-economic aspects of the precariat. However, the analyses will focus primarily on the situation and scale of the precariat in Poland.

If we assume that at present the precariat is young, it means that these are people aged 15-34. The data compiled in Table 1 indicate that in Poland over the last thirteen years, the employment rate of working age people systematically increased, i.e. from $51.4 \%$ in 2004 to $66.1 \%$ in 2017 (close to the EU average). Despite this fact, the employment rate of people aged 15-64 in 2017 was still lower than in the EU-28 (by 1.5 pp). However, it is worth noting that even during the economic crisis, the employment rate in Poland increased-in 2017, it reached $66.1 \%$ (the highest rate since the accession to the European Union). In the EU-28, an opposite trend can be observed. Since the beginning of the economic crisis in 
2008 , this indicator systematically dropped to reach approx. 64\%. The downward trend reversed in 2015, when it reached the highest recorded increase in the employment $-65.6 \%$, which is the closest to that of 2008 (see Table 1). The situation improved for the young people. Although in Poland the percentage of employed persons aged 15-19 compared to the EU-28 is still lower (see Table 1), in the case of other age groups it is at par, and in some cases even higher (in the age group of 25-29 and 30-34 years since 2008).

Table 1. Average annual employment rate by age in Poland and the EU-28 in the years 2004-2017 (percentage)

\begin{tabular}{ccccccccccc}
\hline \multirow{2}{*}{ Category } & \multicolumn{2}{c}{$15-19$} & \multicolumn{2}{c}{ 20-24 } & \multicolumn{2}{c}{ 25-29 } & \multicolumn{2}{c}{ 30-34 } & \multicolumn{2}{c}{ 15-64 } \\
\cline { 2 - 11 } & PL & EU-28 & PL & EU-28 & PL & EU-28 & PL & EU-28 & PL & EU-28 \\
\hline 2004 & 6.0 & 18.2 & 35.0 & 52.4 & 65.6 & 72.9 & 74.2 & 78.2 & 51.4 & 62.7 \\
\hline 2005 & 6.2 & 18.5 & 37.2 & 52.5 & 67.6 & 73.1 & 74.3 & 78.2 & 52.8 & 63.4 \\
\hline 2006 & 5.9 & 18.5 & 40.1 & 53.6 & 70.8 & 74.5 & 76.4 & 78.9 & 54.5 & 64.3 \\
\hline 2007 & 6.2 & 19.2 & 43.4 & 54.8 & 73.7 & 75.3 & 79.4 & 79.8 & 57.0 & 65.3 \\
\hline 2008 & 6.1 & 19.0 & 46.6 & 54.9 & 76.3 & 75.6 & 80.8 & 80.2 & 59.2 & 65.7 \\
\hline 2009 & 5.6 & 17.1 & 46.1 & 51.6 & 75.0 & 73.2 & 80.9 & 78.2 & 59.3 & 64.5 \\
\hline 2010 & 5.7 & 16.0 & 44.7 & 50.4 & 73.8 & 72.4 & 79.8 & 77.7 & 58.9 & 64.1 \\
\hline 2011 & 4.9 & 15.5 & 42.3 & 49.5 & 73.9 & 72.1 & 79.3 & 77.4 & 59.3 & 64.2 \\
\hline 2012 & 4.5 & 15.0 & 41.9 & 48.3 & 73.1 & 71.2 & 79.0 & 76.9 & 59.7 & 64.1 \\
\hline 2013 & 4.2 & 14.8 & 41.0 & 47.8 & 73.0 & 70.5 & 78.5 & 76.5 & 60.0 & 64.1 \\
\hline 2014 & 4.3 & 14.8 & 43.8 & 48.5 & 74.7 & 71.2 & 79.6 & 77.2 & 61.7 & 64.8 \\
\hline 2015 & 4.0 & 15.1 & 44.4 & 49.7 & 75.8 & 72.0 & 81.1 & 77.7 & 62.9 & 65.6 \\
\hline 2016 & 4.5 & 15.7 & 48.4 & 50.7 & 77.7 & 73.2 & 81.3 & 78.0 & 64.5 & 66.6 \\
\hline 2017 & 4.8 & 16.1 & 50.7 & 52.1 & 78.5 & 74.3 & 81.8 & 79.0 & 66.1 & 67.6 \\
\hline
\end{tabular}

Note. Own elaboration based on the Eurostat database: Employment rates by sex, age and nationality (\%).

In the context of employment, the analysis of the structure of the employed according to the level of education seems to be interesting. Table 2 presents data from 2016 for Poland. The people with tertiary education (34\%) were the largest group among the employed persons, those with post-secondary and secondary vocational education as well as basic vocational education constituted a slightly smaller group (27\%). This indicates that there is a need in Poland for tertiary education as well as secondary and basic vocational education. In addition, people with tertiary education constitute the largest part of the population of working people, although often this employment is only marginally related to the work associated with the learnt profession and is not associated with knowledge gained in the course of academic education and qualifications acquired by a university graduate. According to Wężyk (2014), the precariat is "the first class in history that has too high qualifications in relation to the tasks performed". Currently, the university graduate performs the jobs that went to the people with secondary education. 
Table 2. Structure of employment by education level and age in Poland in 2016 (\%)

\begin{tabular}{crccccc}
\hline & & \multicolumn{5}{c}{ Education } \\
\cline { 3 - 7 } Age & $\begin{array}{c}\text { Total } \\
\text { (\%) }\end{array}$ & tertiary & $\begin{array}{c}\text { post-secondary } \\
\text { and secondary } \\
\text { vocational }\end{array}$ & $\begin{array}{c}\text { general sec- } \\
\text { ondary }\end{array}$ & basic vocational & $\begin{array}{c}\text { lower secondary } \\
\text { and primary }\end{array}$ \\
\hline $15-24$ & 6.9 & 13.9 & 35.9 & 23.3 & 18.0 & 8.9 \\
\hline $25-34$ & 26.6 & 47.3 & 24.7 & 11.0 & 13.6 & 3.4 \\
\hline $35-44$ & 27.7 & 39.5 & 24.2 & 7.1 & 25.0 & 4.2 \\
\hline $45-54$ & 21.4 & 25.3 & 27.2 & 5.9 & 36.4 & 5.2 \\
\hline $55-64$ & 15.5 & 21.4 & 32.3 & 5.6 & 33.0 & 7.6 \\
\hline $65+$ & 1.9 & 39.2 & 25.2 & 4.5 & 20.1 & 11.0 \\
\hline total & 100.0 & 34.0 & 27.0 & 8.7 & 25.1 & 5.2 \\
\hline
\end{tabular}

Note. Adapted from “Mały rocznik statystyczny Polski 2017," GUS, 2017, Warszawa, p. 125.

In the recent years, due to the economic crisis, the situation of people in the most difficult position in the market has deteriorated. Table 3 presents data describing how the average annual unemployment rate evolved among young people (from 15 to 34 years of age) in Poland and in the EU-28 over thirteen years, i.e. from 2004 to 2017. It can be seen that until the beginning of the crisis in 2008, this indicator was gradually decreasing, reaching lower values in each of the distinguished age groups. Compared to the EU-28, Poland is doing well, as this indicator decreased by more than 10 percentage points in four years (from $11.6 \mathrm{pp}$ for the 30-34 age group to 26.3 pp for the 20-24 age group). In 2009, the situation changed and for about four to five years, the average annual unemployment rate increased. However, Poland is still lower than it was at the beginning of the first decade of the $21^{\text {st }}$ century, while in the EU-28 it is higher than in the previous years. The young people are among the most affected by the economic crisis (cf. Centrum Badania Opinii Społecznej, 2015).

The unemployment rate in the EU-28 for people in the 15-64 age group dropped to the level of $7.1 \%$ in 2008 and then started to grow, reaching $11.0 \%$ in 2013. In Poland, the changes were more favourable. The unemployment rate dropped from more than $19.4 \%$ in 2004 to $7.2 \%$ in 2008 , and then it increased to $10.5 \%$ in 2013 . The situation of people under 25 was much worse. In this age group, the unemployment rate in the EU-28 fell from over $18.7 \%$ in 2004 to less than $15.6 \%$ in 2008 , and then it increased to $23.7 \%$ in 2013 . In 2017 , it was at the level similar to that of 2004-16.8\%. In turn, in Poland, the unemployment rate of the youngest participants in the labour market decreased from almost $40.1 \%$ in 2004 to $17.3 \%$ in 2008 and then increased to over $27.3 \%$ in 2013. In 2017, the lowest unemployment rate-14.8\% - since the accession to the European Union was recorded. It should be added that probably the unemployment rate among this age group in Poland would have been higher, however, these are mostly people born in the period of a drop in the birth rate. 
THE PHENOMENON OF THE PRECARIAT...

Table 3. Average annual unemployment rate by age in Poland and the EU-28 in the years 2004-2017 (percentage)

\begin{tabular}{rrrrrrrrrrr}
\hline \multirow{2}{*}{ Category } & \multicolumn{2}{c}{$15-19$} & \multicolumn{2}{c}{ 20-24 } & \multicolumn{2}{c}{ 25-29 } & \multicolumn{2}{c}{ 30-34 } & \multicolumn{2}{c}{$15-64$} \\
\cline { 2 - 12 } & PL & EU-28 & PL & EU-28 & PL & EU-28 & PL & EU-28 & PL & EU-28 \\
\hline 2004 & 37.8 & 20.6 & 40.4 & 18.0 & 22.6 & 11.4 & 16.0 & 8.4 & 19.4 & 9.3 \\
\hline 2005 & 35.7 & 21.5 & 37.0 & 17.7 & 20.2 & 11.0 & 14.9 & 8.2 & 18.0 & 9.0 \\
\hline 2006 & 30.8 & 21.4 & 29.6 & 15.9 & 15.3 & 9.9 & 11.6 & 7.6 & 14.0 & 8.3 \\
\hline 2007 & 22.2 & 20.0 & 21.6 & 13.9 & 10.6 & 8.7 & 8.2 & 6.7 & 9.7 & 7.2 \\
\hline 2008 & 20.1 & 20.4 & 16.9 & 13.9 & 8.2 & 8.5 & 5.9 & 6.6 & 7.2 & 7.1 \\
\hline 2009 & 27.4 & 24.9 & 19.8 & 18.2 & 9.8 & 11.4 & 6.5 & 8.8 & 8.3 & 9.0 \\
\hline 2010 & 30.5 & 26.4 & 22.8 & 19.3 & 12.0 & 12.5 & 7.9 & 9.6 & 9.7 & 9.7 \\
\hline 2011 & 33.5 & 27.4 & 24.9 & 19.9 & 12.0 & 12.7 & 8.1 & 9.8 & 9.8 & 9.8 \\
\hline 2012 & 37.7 & 28.7 & 25.3 & 21.5 & 13.1 & 13.9 & 8.4 & 10.8 & 10.2 & 10.6 \\
\hline 2013 & 37.0 & 28.3 & 26.3 & 22.3 & 13.6 & 14.6 & 8.7 & 11.2 & 10.5 & 11.0 \\
\hline 2014 & 35.9 & 26.7 & 22.7 & 20.9 & 11.8 & 13.6 & 8.0 & 10.5 & 9.1 & 10.4 \\
\hline 2015 & 32.9 & 24.7 & 19.7 & 19.0 & 10.1 & 12.4 & 6.5 & 9.6 & 7.6 & 9.6 \\
\hline 2016 & 32.2 & 22.8 & 16.3 & 17.4 & 8.1 & 11.2 & 5.6 & 8.8 & 6.2 & 8.7 \\
\hline 2017 & 23.0 & 21.0 & 14.1 & 15.5 & 5.9 & 10.0 & 4.4 & 7.8 & 5.0 & 7.8 \\
\hline
\end{tabular}

Note. Adapted from the Eurostat database: Unemployment rates by sex, age and citizenship (\%).

The data compiled in Table 4 show how the average annual long-term unemployment rate developed in recent years (45.2\% in 2017 - an increase of 8.1 percentage points from 2008). Until 2014, it showed an upward trend; only since 2015 , the trend has reversed. It is worth noting that almost half of unemployed people in the EU-28 remain unemployed for more than 12 months. In Poland, this percentage increased between 2009 and 2014 from $30.3 \%$ to $42.7 \%$. As in the EU28, a reverse trend can be observed from 2015.

Another important problem, referring in particular to the situation of young people in the labour market, is related to the time limitations of employment (see Table 5). In recent years, a clear increase in the number of temporary employment offers, i.e. non-standard forms of employment (including the so-called junk jobs), can be seen. This trend and its socio-economic consequences are the subject of controversy because the question arises as to whether temporary work should be treated as an opportunity or a threat. ${ }^{7}$ Increasing the flexibility of labour markets, work organisation and labour relations, while taking into account the reconciliation of work and private life, employment security and social protection in line with the concept of flexicurity (Cymbranowicz, 2014, pp. 203-212; 2015, pp. 17-28) is an opportunity, especially for young people who start their careers, but only if the so-called non-standard forms of employment are a solely transition-

\footnotetext{
7 "There has been a dispute between researchers over the years whether fixed-term work is an introduction to stable employment or rather a dead end. On the one hand, there is the argument that fixed-term contracts allow the employer to test a new employee before hiring this person permanently. On the other hand, a lack of a long-term relationship between the employer and the employee may make it unprofitable to invest in the professional development of a person working for a fixed period of time, which would result in a lower chance of promotion. As a result, temporary employment could become for the employee a trap which over time it would be even harder to escape" (Kiersztyn, 2014, p. 6).
} 
al stage on the way to obtaining permanent employment under a full-time employment contract for an indefinite period. ${ }^{8}$

Table 4. Average annual long-term unemployment rate as a percentage of all unemployed by age in Poland and the EU-28 in the years 2004-2017 (percentage)

\begin{tabular}{ccccccccccc}
\hline \multirow{2}{*}{ Category } & \multicolumn{2}{c}{$15-19$} & \multicolumn{2}{c}{ 20-24 } & \multicolumn{2}{c}{ 25-29 } & \multicolumn{2}{c}{$30-34$} & \multicolumn{2}{c}{$15-64$} \\
\cline { 2 - 12 } & PL & EU-28 & PL & EU-28 & PL & EU-28 & PL & EU-28 & PL & EU-28 \\
\hline 2004 & 31.7 & 21.0 & 45.6 & 35.2 & 51.1 & 39.9 & 52.5 & 43.7 & 53.7 & 45.0 \\
\hline 2005 & 22.5 & 20.1 & 47.8 & 35.4 & 56.6 & 41.0 & 56.2 & 44.6 & 57.7 & 46.2 \\
\hline 2006 & 16.2 & 20.6 & 46.1 & 34.3 & 53.6 & 41.1 & 59.1 & 44.7 & 56.2 & 46.0 \\
\hline 2007 & 13.6 & 18.0 & 37.3 & 30.7 & 45.5 & 36.8 & 54.9 & 42.0 & 51.4 & 42.9 \\
\hline 2008 & NDA & 15.8 & 24.1 & 26.6 & 29.4 & 31.0 & 35.7 & 35.0 & 33.5 & 37.1 \\
\hline 2009 & 11.3 & 17.8 & 22.7 & 25.8 & 26.7 & 28.4 & 28.8 & 31.0 & 30.3 & 33.3 \\
\hline 2010 & 11.7 & 20.5 & 21.9 & 32.1 & 28.9 & 35.3 & 28.8 & 39.3 & 31.1 & 39.9 \\
\hline 2011 & 15.4 & 21.0 & 28.0 & 34.0 & 32.9 & 38.6 & 37.2 & 42.3 & 37.2 & 42.9 \\
\hline 2012 & 13.0 & 22.3 & 33.2 & 36.6 & 37.8 & 40.7 & 39.9 & 43.8 & 40.3 & 44.5 \\
\hline 2013 & 15.4 & 22.2 & 34.0 & 38.5 & 41.7 & 43.6 & 42.1 & 45.9 & 42.5 & 47.3 \\
\hline 2014 & 17.2 & 22.6 & 33.3 & 40.5 & 40.4 & 44.2 & 43.0 & 48.9 & 42.7 & 49.6 \\
\hline 2015 & NDA & 20.0 & 32.3 & 37.2 & 35.9 & 43.1 & 40.9 & 46.8 & 39.3 & 48.5 \\
\hline 2016 & NDA & 18.0 & 27.6 & 34.1 & 32.3 & 40.2 & 33.4 & 45.6 & 34.9 & 46.8 \\
\hline 2017 & NDA & 16.4 & 23.3 & 33.0 & 27.2 & 39.0 & 26.1 & 44.1 & 31.0 & 45.2 \\
\hline
\end{tabular}

Note. Adapted from the Eurostat database: Long-term unemployment (12 months or more) as a percentage of the total unemployment, by sex, age and citizenship (\%), NDA-no data available.

There are particular reasons for concern in Poland, as the percentage of employees working under fixed-term contracts is high and exceeds the EU average by approx. 45\%. In the EU-28, among all people working in the 15-64 age group, approx. $14 \%$ of people were working temporary jobs. This trend is maintained, as in the years $2004-2017$ from $13.2 \%$ to $14.3 \%$ of people aged 15-64 had fixedterm contracts. In Poland, more than 1/4 of employees had the same type of contract, with the lowest percentage reported in 2004 (22.5\%) and the highest in 2014 $(28.3 \%)$.

In this respect, it is worth emphasising that the precariat class is the most strongly represented in the youngest age groups. Undoubtedly, work based on a fixed-term contract dominates among young people because they accept it. It is because young people are just entering the labour market, and they are de facto learning to practise their profession, i.e. "learning the ropes" (cf. Centrum Badania Opinii Społecznej, 2014). Such employment is considered an introduction to the full-time job, but as evident in Table 5; this form of employment is currently be-

\footnotetext{
8 "For many employees, non-standard forms of employment are a dead end rather than a transitional stage on the road to getting a permanent job - state the authors of the POLPAN report, showing changes in the labour market. The experts checked in 2013 what was happening with people who in 2008 had had a non-standard form of employment. It turned out that after five years of working under civil or temporary contracts only less than $37 \%$ of the respondents received a contract for an indefinite period and 5\% became self-employed. And the remaining ones-almost 60 percent!- were still becoming acquainted with the charms of civil and temporary contracts or did not work at all (21\%)" (Popiołek \& Kiełbasiński, 2014).
} 
coming the norm. Over the last thirteen years, in the EU-28, with the exception of 2007-2009 and 2012-2013, there has been a steady increase in the proportion of workers employed for short terms. For people under the age of 25 in the EU-28, this rate is maintained at the level between $37.6 \%$ and $44.2 \%$. Against this background, Poland definitely looks worse because an upward trend has persisted since 2008 and the proportion of workers employed for a fixed-term is above the EU average-growing from $60.6 \%$ in 2004 to 68.2 in 2017 (the highest level was recorded in 2015-72.7 percentage). Referring to the data compiled in Table 3, a very high percentage of people working under such contracts in the youngest age group (15-19 years and 20-24 years) can be explained, on the one hand, by a lack of need for stable employment on the part of young people, and on the other hand, by an abuse of this form of employment by employers. However, real anxiety can be caused by almost twice higher in Poland than in the EU-28 percentage of people in the age groups above 20 and 25 years of age, because at this age, job and income stability become one of the basic professional and life needs.

Table 5. Employees with a fixed-term contract as a percentage of all employees by age in Poland and the EU-28 in the years 2004-2017 (percentage)

\begin{tabular}{ccccccccc}
\hline \multirow{2}{*}{ Category } & \multicolumn{2}{c}{$15-19$} & \multicolumn{2}{c}{$20-24$} & \multicolumn{2}{c}{ 25-29 } & \multicolumn{2}{c}{$15-64$} \\
\cline { 2 - 9 } & PL & EU-28 & PL & EU-28 & PL & EU-28 & PL & EU-28 \\
\hline 2004 & 84.5 & 50.8 & 58.1 & 33.3 & 33.8 & 19.1 & 22.5 & 13.2 \\
\hline 2005 & 88.0 & 53.3 & 62.8 & 35.7 & 38.8 & 20.8 & 25.6 & 14.0 \\
\hline 2006 & 89.6 & 54.3 & 65.0 & 36.5 & 38.2 & 21.5 & 27.3 & 14.5 \\
\hline 2007 & 86.2 & 55.6 & 63.6 & 36.6 & 39.1 & 21.3 & 28.2 & 14.6 \\
\hline 2008 & 85.7 & 54.2 & 60.4 & 35.6 & 36.1 & 21.0 & 26.9 & 14.1 \\
\hline 2009 & 91.4 & 55.6 & 59.1 & 35.8 & 36.2 & 20.2 & 26.4 & 13.6 \\
\hline 2010 & 86.8 & 56.8 & 62.4 & 38.0 & 37.9 & 21.2 & 27.2 & 13.9 \\
\hline 2011 & 88.8 & 56.9 & 63.7 & 38.4 & 39.4 & 22.1 & 26.8 & 14.0 \\
\hline 2012 & 89.5 & 56.1 & 64.7 & 38.3 & 40.4 & 22.0 & 26.8 & 13.7 \\
\hline 2013 & 91.6 & 56.9 & 66.8 & 38.3 & 40.9 & 22.2 & 26.8 & 13.6 \\
\hline 2014 & 93.5 & 58.1 & 69.6 & 39.1 & 43.5 & 22.7 & 28.3 & 13.9 \\
\hline 2015 & 93.8 & 57.2 & 71.2 & 39.4 & 43.8 & 23.1 & 28.0 & 14.1 \\
\hline 2016 & 92.5 & 58.1 & 69.1 & 39.6 & 43.3 & 23.0 & 27.5 & 14.2 \\
\hline 2017 & 91.1 & 59.1 & 66.4 & 39.9 & 40.4 & 22.8 & 26.1 & 14.3 \\
\hline
\end{tabular}

Note. Adapted from the Eurostat database: "Temporary employees as percentage of the total number of employees, by sex, age and citizenship (\%)" and "Young temporary employees as percentage of the total number of employees, by sex, age and country of birth (percentage)." No data available for people in the 30-34 age group.

Referring to the Polish realities, Kaleta, in his article entitled Prekariat to ogromny problem: Kto utrzyma ludzi po umowach śmieciowych, gdy przyjdzie czas ich emerytur? [The Precariat Is a Huge Problem: Who Will Support People Working on Junk Contracts When Their Retirement Time Comes?] says that young people are often employed on "prolonged internships, trial periods or under fixed-term contracts" (Kaleta, 2015). This is a common practice, as it is treated as "testing" an employee in a new workplace and teaching this employee to perform specific duties. The assumption behind doing this kind of work is the long-term "promotion", i.e. an offer of the so-called full-time employment. In reality, how- 
ever, after the time specified in the contract the employee is not "promoted"- the employer offers another contract under the same conditions as the previous one or resigns from services of this particular employee, dismissing the person. In such cases, young people not only remain without a perspective for a permanent job which could stabilise their life situation but are deprived of a job altogether. This is a dangerous phenomenon that leads to the deepening of economic (inactivity, short- and long-term unemployment, poverty) and social problems (marginalisation, exclusion).

Another problem faced currently by people taking up employment is related to full-time and part-time work. In this respect, the situation in Poland looks better than in the EU-28 (see Table 6).

Table 6. Part-time work by age in Poland and the EU-28 in the years 2004-2017 (percentage)

\begin{tabular}{ccccccccc}
\hline \multirow{2}{*}{ Category } & \multicolumn{2}{c}{$15-19$} & \multicolumn{2}{c}{$20-24$} & \multicolumn{2}{c}{ 25-29 } & \multicolumn{2}{c}{ 15-64 } \\
\cline { 2 - 9 } & PL & EU-28 & PL & EU-28 & PL & EU-28 & PL & EU-28 \\
\hline 2004 & 57.0 & 40.5 & 15.1 & 18.3 & 8.5 & 12.4 & 9.6 & 16.7 \\
\hline 2005 & 59.7 & 40.5 & 17.0 & 19.3 & 8.3 & 13.0 & 9.8 & 17.2 \\
\hline 2006 & 56.0 & 42.3 & 14.4 & 19.7 & 7.0 & 13.2 & 8.9 & 17.5 \\
\hline 2007 & 50.4 & 42.4 & 13.0 & 19.9 & 6.8 & 13.1 & 8.5 & 17.5 \\
\hline 2008 & 42.7 & 44.4 & 10.8 & 20.4 & 5.9 & 13.2 & 7.7 & 17.5 \\
\hline 2009 & 43.8 & 46.4 & 11.0 & 22.2 & 5.7 & 13.8 & 7.7 & 18.0 \\
\hline 2010 & 47.5 & 48.1 & 12.0 & 23.7 & 5.8 & 14.6 & 7.7 & 18.5 \\
\hline 2011 & 49.7 & 49.0 & 12.0 & 24.4 & 5.8 & 15.4 & 7.3 & 18.8 \\
\hline 2012 & 53.5 & 50.7 & 13.4 & 25.8 & 5.8 & 15.9 & 7.2 & 19.2 \\
\hline 2013 & 50.0 & 50.7 & 13.3 & 26.9 & 6.2 & 16.7 & 7.1 & 19.6 \\
\hline 2014 & 50.2 & 49.9 & 12.5 & 26.8 & 6.6 & 17.0 & 7.1 & 19.6 \\
\hline 2015 & 46.1 & 51.0 & 11.8 & 27.0 & 6.1 & 17.1 & 6.8 & 19.6 \\
\hline 2016 & 46.7 & 51.4 & 10.7 & 27.0 & 5.6 & 16.9 & 6.4 & 19.5 \\
\hline 2017 & 54.6 & 51.6 & 11.2 & 26.8 & 5.0 & 16.5 & 6.6 & 19.4 \\
\hline
\end{tabular}

Note. Adapted from the Eurostat database: "Part-time employment as percentage of the total employment, by sex and age (\%)" and "Part-time employment as percentage of the total employment for young people by sex, age and country of birth (percentage). No data available for people in the 30-34 age group."

In the EU-28, since 2004 an upward trend in the share of people aged 15-64 years employed in part-time work has been observed, from 16.7\% in 2004 to $19.4 \%$ in 2017 , i.e. an increase of 2.7 percentage points over the last thirteen years (the highest rate was maintained in 2013-2015, i.e. 19.6\%). On the other hand, there is a reverse trend observed in Poland-from $9.6 \%$ in 2004 to $6.6 \%$ in 2017 , i.e. a decrease of 3 percentage points. The structure of young people working full-time and part-time is of significant importance from the perspective of identifying the precariat in Poland. If we consider only these people, it turns out that their situation in Poland is better than in the EU-28. Although in Poland the percentage of people employed part-time at the age of 15-19 compared to the EU28 is still slightly higher (which can be explained by the fact that this age group remains outside the labour market due to education), in the case of other age groups it is significantly lower (see Table 6). 
The analyses presented above concerned mainly the situation of the young people in the labour market in Poland compared to the other EU Member States over the past thirteen years. The conducted analysis attempts to draw attention to the issue of precarity of employment within the framework of the so-called nonstandard forms of employment and the consequences that this phenomenon brings. Opportunities and threats in the socio-economic dimension related to the occurrence of the precariat phenomenon in the labour market in Poland are, however, a topic that merits a separate study.

\section{Conclusions}

The problem formerly described simply as "youth unemployment" in the course of the deepening global economic crisis has taken on a much wider dimension and earned its own name: the precariat. The similarity to the famous term proletariat is obviously not accidental. However, this word and the related phenomenon have relatively recently become permanent in social and economic terminology, hence it is not yet possible to determine if the precariat class can also have such a great impact on modern reality as the working class once had.

The emergence of the precariat in the modern labour market is undoubtedly a negative phenomenon. From the perspective of the future development of the labour market not only in Poland but also in the European Union, issues related to the further fate of the class known as the precariat can become extremely important. This phenomenon concerns a broad social group, consisting most often of people just starting their professional career, who in the near future will begin to dominate the labour market exerting the greatest influence on it. In this case, the acquired experience and professional skills, or their deficit, resulting from discouragement caused by a lack of development prospects and the chance to perform a permanent, profitable job or even by the inability to secure stable private and family life, may be crucial. The deepening social divisions can lead to an increase in the precariat class, which will be joined by new young people after the end of their education. This phenomenon, therefore, deserves special attention not only due to the current situation of employees but also as a potential threat to the stabilised labour market in the future.

\section{References}

Centrum Badania Opinii Społecznej. (2014). Polacy w pracy. Warunki zatrudnienia, gotowość zmian [Komunikat z badań CBOS, No. 132]. Warszawa. http://www.cbos.pl/ SPISKOM.POL/2014/K_132_14.PDF

Centrum Badania Opinii Społecznej. (2015). Ocena sytuacji na rynku pracy i poczucie zagrożenia bezrobociem, [Komunikat $\mathrm{z}$ badań CBOS, No. 53]. Warszawa. http://www.cbos.pl/SPISKOM.POL/2015/K_053_15.PDF 
Cymbranowicz, K. (2014). Flexicurity - A New Tool for Human Recourses Management. In P. Lula, \& T. Rojek (Eds.), Knowledge - Economy - Society: Contemporary Tools of Organizational Resources Management. Crakow: Faculty of Management of the Cracow University of Economics - Foundation of the Cracow University of Economics.

Cymbranowicz, K. (2015). The Impact of Flexicurity on the Functioning of the Labour Market in the European Union. In A. Malina, R. Oczkowska, \& J. Kaczmarek (Eds.), Knowledge - Economy - Society: Challenges and Development Trends of Modern Economy, Finance and Information Technology. Cracow: Faculty of Management of the Cracow University of Economics - Foundation of the Cracow University of Economics.

Cymbranowicz, K. (2016). Prekariat - nowe zjawisko na rynku pracy w Polsce. Annales. Ethics in Economic Life, 19(2), 17-30.

GUS [Central Statistical Office of Poland]. (2017). Mały rocznik statystyczny Polski 2017. Warszawa: GUS.

Hanyga, K. (2012). Pęczniejący prekariat. Sprawy Nauki, 10 (173). http://www.sprawyna uki.edu.pl/index.php?option=com_content $\&$ view $=$ article $\& i d=2305$ :prekaryzacja-wofensywie \&catid $=301 \&$ Itemid $=30$

Jourdan, S. (2012). Le précariat: «Une classe sociale en devenir». Néo-libéralisme. http:// www.bastamag.net/Le-precariat-Une-classe-sociale-en

Kaleta, W. (2015, 29 June). Prekariat to ogromny problem: Kto utrzyma ludzi po umowach śmieciowych, gdy przyjdzie czas ich emerytur? pulsHR.pl. https://www.pulshr.pl/pra wo-pracy/prekariat-to-ogromny-problem-kto-utrzyma-ludzi-po-umowach-smieciowych -gdy-przyjdzie-czas-ich-emerytur,27043.html

Kancelaria Prezesa Rady Ministrów. (2011). Raport “Młodzi 2011.” Warszawa.

Kiersztyn, A. (2014). Niepewność zatrudnienia. Kto jej doświadcza? Czy to stan chwilowy? Warszawa: Zespół Porównawczych Analiz Nierówności Społecznych, Instytut Filozofii i Socjologii Polskiej Akademii Nauk.

Kozek, W. (2013). Rynek pracy. Perspektywa instytucjonalna. Warszawa: Wydawnictwo Uniwersytetu Warszawskiego.

Poławski, P. (2012). Generacja prekariuszy na polskim rynku pracy. Polityka Spoleczna, 9, $16-23$.

Popiołek, A., \& Kiełbasiński, A. (2014, March 31). Młodzi bez etatu i bez szans. Stracone pokolenie? Gazeta Wyborcza, 75. http://wyborcza.pl/1,76842,15713351,Mlodzi_ bez_etatu_i_bez_szans_Stracone_pokolenie_html

Savage, M. (2013). A new model of social class? Findings from the BBC's Great British class survey experiment. Sociology, 47(2), 219-250.

Smoczyński, W. (2011, September 7). Prekariusze wszystkich krajów. Polityka, 37(2824). http://www.polityka.pl/tygodnikpolityka/swiat/1519162,1,prekariat-mlodzi-bez-per spektyw-no wa-klasa-spoleczna.read

Standing, G. (2011a). The precariat. The new dangerous class. London-New York: Bloomsbury Academic.

Standing, G. (2011b). The Precariat: The New Dangerous Class. GCPH Seminar Series 8. https://www.guystanding.com/files/documents/The_Precariat_final_summary_GC PH_Nov_11.pdf 
Szaban, J. (2013). Rynek pracy w Polsce $i$ w Unii Europejskiej. Warszawa: Wydawnictwo Difin.

Vostal, F. (2014). Prekaryjność socjologii. Notatki z Czech. Globalny Dialog, 4(3), 39-40.

Wężyk, K. (2014, November 22-23). Wyklęty lud ziemi, o jakim Marksowi się nie śniło. Gazeta Wyborcza, 271. http://wyborcza.pl/magazyn/1,142071,17 000733,Wyklety_ lud_ziemi_o_jakim_Marksowi_sie_nie_snilo.html 